\title{
An Effective way of improving the Course Outcomes by using Jigsaw Technique in Core Courses of Engineering
}

\author{
R.Suganya ${ }^{1}$, D. Kavitha ${ }^{2}$, R. Helen ${ }^{3}$ \\ Department of Electrical and Electronics Engineering, \\ Thiagarajar College of Engineering, Madurai - 625019 \\ ${ }^{1}$ rsaeee@tce.edu \\ 22dkeee@tce.edu \\ ${ }^{3}$ rheee@tce.edu
}

\begin{abstract}
Jigsaw is a cooperative learning method that makes students dependent on each other to achieve the team goals or to understand the concepts. Many faculties in engineering college struggle with the students to make them to understand the technical concepts. A case study was done on the course Microcontroller for B.E fourth semester Electrical Engineering students (2018-2019 Even semester).The process is tested with two different set of students Group A and Group B. The Group A students learning method is traditional classroom lecture and Jigsaw Technique is implemented in Group B. The student's understandability on that Course outcome is evaluated based on their Continuous Assessment Test-II and their Satisfactory Index towards the Course Outcome using Canvas LMS. From the case study, Student's satisfactory index is high when learning is based on Jigsaw technique.
\end{abstract}

Keywords: Outcome Based Education (OBE), Learning Management system (LMS), Continuous Assessment TestII (CAT-II), active teaching and learning strategies, peer-topeer learning.

\section{Introduction}

Traditional classroom learning is very passive with lecturing and listening. Conventional teaching methods like workbook, black board lecture; homework and assessment test for student learning has received much denigration in modern years. Today students like to learn by participating and interacting than listening lectures. The Fourth Industrial Revolution represents a primary change in the way we live, job and share to one another with extraordinary technology advancement. The actual opportunity is to appear beyond technology and find ways to offer the greatest number of people the capability to optimistically impact their families, organisations and communities. Usage of technology and smart way learning is important in education.

Active learning approach is more booming mode of learning which helps in internalizing the concepts and easy way of recalling the concepts [1]. Several active learning techniques are involved like debates [2], game based learning [3], Group role-play [4], and problem based learning and project-based learning [5]. There are different types of active learning method, where the students do incredible to acquire knowledge instead of listening. Handson laboratory like virtual labs are also one of active learning to improve the student in learning electrical and electronic circuit courses. It first makes them "visible" and "accountable" in the classroom, and then by offering that hands-on practice through the use free and open source simulation software

This paper illustrates the progress of learning by implementing Jigsaw technique. It is done as a case study in the course 'Microcontroller' for B.E Electrical and Electronics students at Thiagarajar College of Engineering, an autonomous institution affiliated to Anna University at India. The process is tested with two different set of students Group A and Group B. The Group A students learning method is traditional classroom lecture and Group B learning method is using Jigsaw Technique. In this paper, the Chapter 1 deals with the introduction part and literature survey. Chapter 2 discusses about the Microcontrollers course. Chapter 3 describes the Jigsaw techniques. Chapter 4 describes the Implementation procedure of Jigsaw techniques. Chapter 5 deals with Discussions on Results. Chapter 6 is Conclusion.

\section{About The Microcontrollers Course}

The course taken for case study is '14EE460 Microcontrollers ' which is a Program Core Course for Forth semester, B.E Electrical and Electronics Engineering students at Thiagarajar College of Engineering, an autonomous institution affiliated to Anna University at India. The syllabus of the course under study covers the architecture and peripherals of 8051 microcontrollers, assembly language, embedded programming and advance microcontrollers such as PIC16F877 and ARM7 (LPC2148). The concept map illustrating the syllabus is given in Fig. 1 


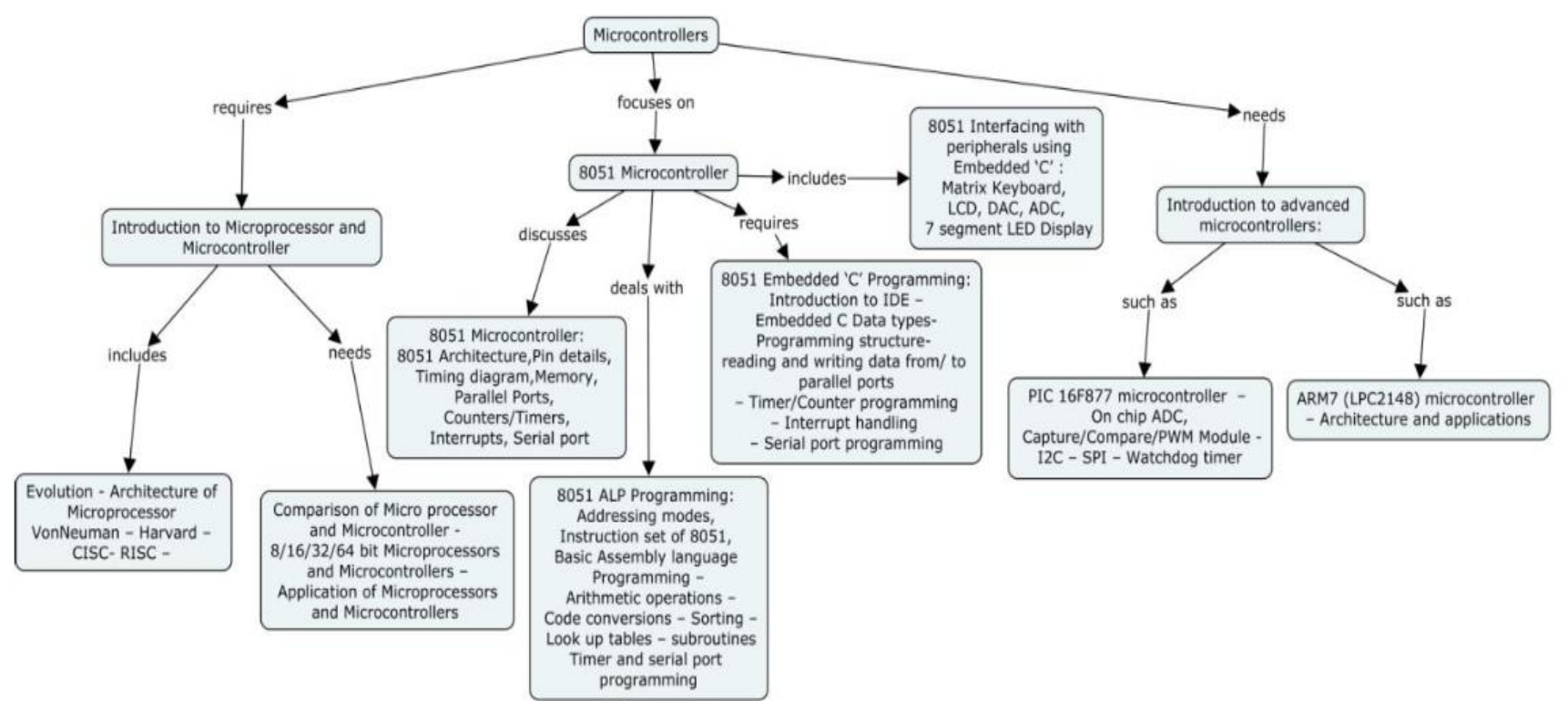

Fig. 1: Concept map of the course "Microcontrollers

The Table I explain the course outcomes of the Microcontrollers course under study with their Bloom's level.

Table I COURSE OUTCOME FOR "MICROCONTROLLERS"

\begin{tabular}{|c|c|c|}
\hline $\begin{array}{l}\text { COs } \\
\text { No }\end{array}$ & Course outcomes & $\begin{array}{c}\text { Blooms } \\
\text { level }\end{array}$ \\
\hline $\mathrm{CO} 1$ & $\begin{array}{l}\text { Explain the evolution and } \\
\text { architecture of microprocessors } \\
\text { and microcontrollers. }\end{array}$ & Understand \\
\hline $\mathrm{CO} 2$ & $\begin{array}{l}\text { Explain the } 8051 \text { architecture and } \\
\text { the function of on-chip hardware } \\
\text { units in } 8051 .\end{array}$ & Understand \\
\hline $\mathrm{CO} 3$ & $\begin{array}{l}\text { Develop } 8051 \text { Assembly } \\
\text { Language programs for data } \\
\text { manipulations and accessing on- } \\
\text { chip hardware units. }\end{array}$ & Apply \\
\hline $\mathrm{CO} 4$ & $\begin{array}{l}\text { Develop } 8051 \text { embedded C } \\
\text { programs for interfacing Matrix } \\
\text { Keyboard LCD, DAC, ADC and } \\
\text { 7segment LED Display }\end{array}$ & Apply \\
\hline $\mathrm{CO} 5$ & $\begin{array}{l}\text { Explain the architecture and } \\
\text { hardware features of PIC 16F877 } \\
\text { and ARM7 (LPC2148). }\end{array}$ & Understand \\
\hline
\end{tabular}

As per the college policy, the questions will be framed based on blooms category in Continuous Assessment Tests and Terminal Examination. Table II explains Assessment Pattern for Microcontrollers course with their Bloom's level.

Table II Assessment Pattern for "MICROCONTROLLERS"

\begin{tabular}{|l|l|l|l|l|}
\hline \multirow{2}{*}{$\begin{array}{l}\text { Bloom's } \\
\text { Category }\end{array}$} & \multicolumn{2}{|l|}{$\begin{array}{l}\text { Continuous Assessment } \\
\text { Tests }\end{array}$} & $\begin{array}{l}\text { Terminal } \\
\text { Examination }\end{array}$ \\
\cline { 2 - 4 } & $\mathbf{1}$ & $\mathbf{2}$ & $\mathbf{3}$ & \\
\hline Remember & 40 & 20 & 20 & 20 \\
\hline Understand & 40 & 20 & 20 & 20 \\
\hline Apply & 20 & 60 & 60 & 60 \\
\hline
\end{tabular}

\begin{tabular}{|l|l|l|l|l|}
\hline Analyse & 0 & 0 & 0 & 0 \\
\hline Evaluate & 0 & 0 & 0 & 0 \\
\hline Create & 0 & 0 & 0 & 0 \\
\hline
\end{tabular}

\section{Jigsaw Techniques:}

The jigsaw classroom is a research-based cooperative learning technique invented and developed in the 1970s by Elliot Aronson and his students at the University of Texas and the University of California with great success. The cooperative learning strategy is known as the "jigsaw" technique, which helps students create their own learning [6-8]. Educator arranges students in groups. Each group member is assigned a different sets of questions related with the same topic. Group members then join with members of other groups and share their information or ideas about the information. Finally, students return to their original groups and discuss their sets of questions to understand the topic.

Jigsaw technique is very easy and simple to use. There are 10 steps to be followed for conducting jigsaw techniques. Steps are discussed in the figure 2. The students are divided into 5- or 6-person to form jigsaw group and then select one student from each group as the leader. Divide the day's session topics into 5-6 segments and assign them to each student to learn one segment on their own by proving materials. Form temporary "expert groups" by having one student from each jigsaw group to join with other students assigned to the same piece of questions for discussion and bring the students back into their jigsaw groups. Ask each student to present her or his segment to the group. At the end of the session, give a quiz on the material. 


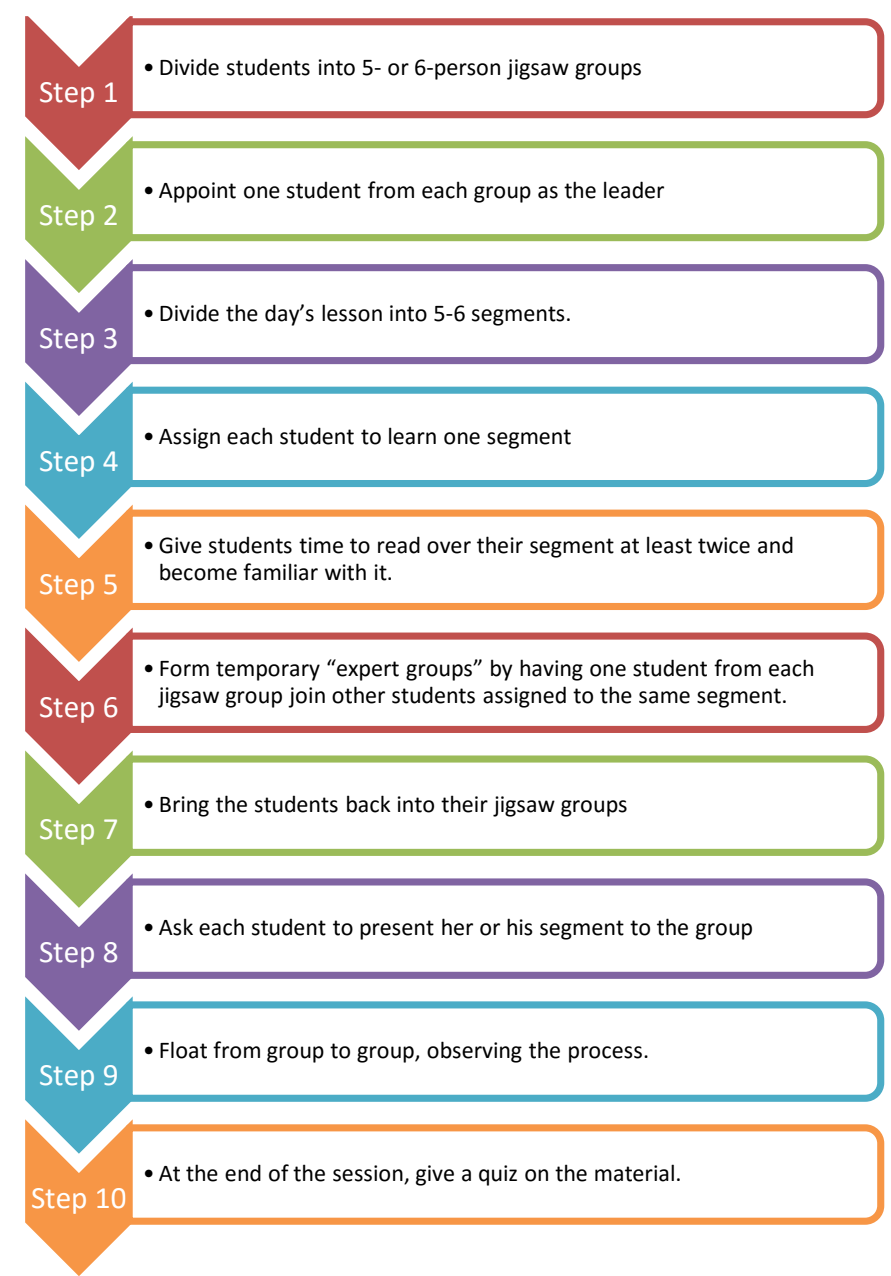

Figure 2 Flow chart for Jigsaw technique

\section{Implementation of Jigsaw techniques}

For Jigsaw implementation, Learning materials are sent as e-documents to their Learning Management system (LMS) Canvas Instructure [9]. Students are divided and form a jigsaw group with 4 students in a group. Then select one student from each group as the leader. Course Outcome 3 (CO3) is consider for Jigsaw implementation with four questions Q1, Q2, Q3 and Q4 explains in figure 3. Learn one question on their own using as e-documents send to their Learning Management system (LMS) Canvas Instructure.

Table III Jigsaw implementation questions for assessment of $\mathrm{CO} 3$

\begin{tabular}{|l|l|l|}
\hline $\begin{array}{l}\text { Question } \\
\text { no }\end{array}$ & Questions & $\begin{array}{l}\text { Course } \\
\text { outcome } \\
\text { (CO) }\end{array}$ \\
\hline & $\begin{array}{l}\text { Generation of 500Hz square } \\
\text { waveform using timer 1 of 8051 } \\
\text { Microcontroller at port pin P0.4 }\end{array}$ & $\begin{array}{l}\text { Apply } \\
\text { Apply }\end{array}$ \\
\hline Q2 & $\begin{array}{l}\text { Generation of 1kHz rectangular } \\
\text { waveform with 75\% duty cycle } \\
\text { using timer 1 of 8051 } \\
\text { Microcontroller at port pin } \\
\text { P2.4. Apply }\end{array}$ & \\
\hline Q3 & $\begin{array}{l}\text { Generation of 25 kHz square } \\
\text { waveform using interrupt }\end{array}$ & $\begin{array}{l}\text { CO3- } \\
\text { Apply }\end{array}$ \\
\hline
\end{tabular}

\begin{tabular}{|l|l|l|}
\hline & $\begin{array}{l}\text { concept of 8051 Microcontroller } \\
\text { at port pin P1.4. }\end{array}$ & \\
\hline Q4 & $\begin{array}{l}\text { Counting the number of } \\
\text { incoming pulses using counters } \\
\text { of 8051 Microcontroller }\end{array}$ & $\begin{array}{l}\text { CO3- } \\
\text { Apply }\end{array}$ \\
\hline
\end{tabular}

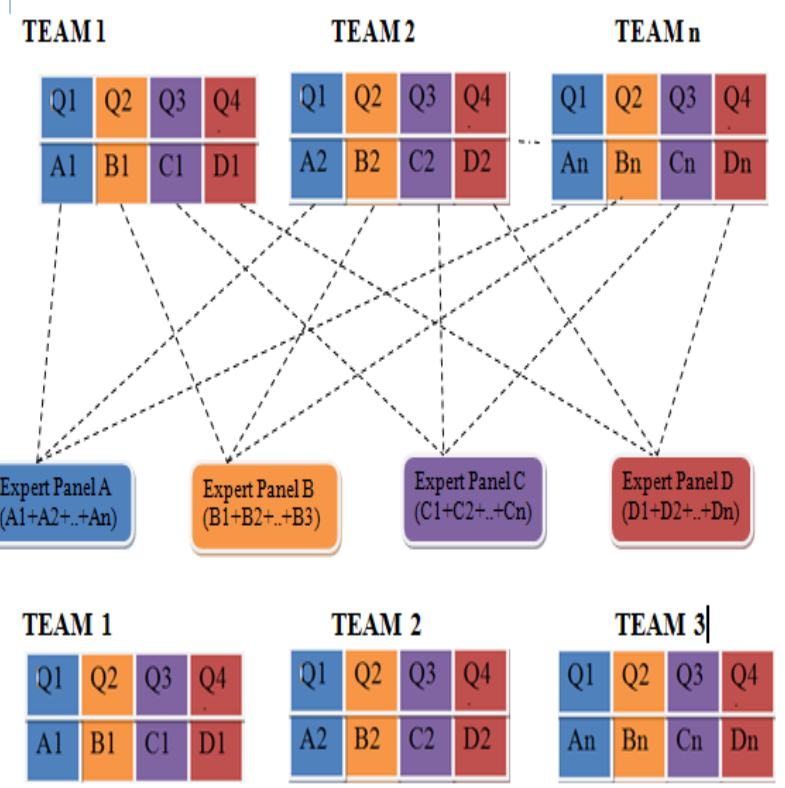

Figure 3 Implementation procedure

Form temporary "expert groups" by having one student from each jigsaw group to join with other students to discuss the questions and bring the students back into their jigsaw groups.

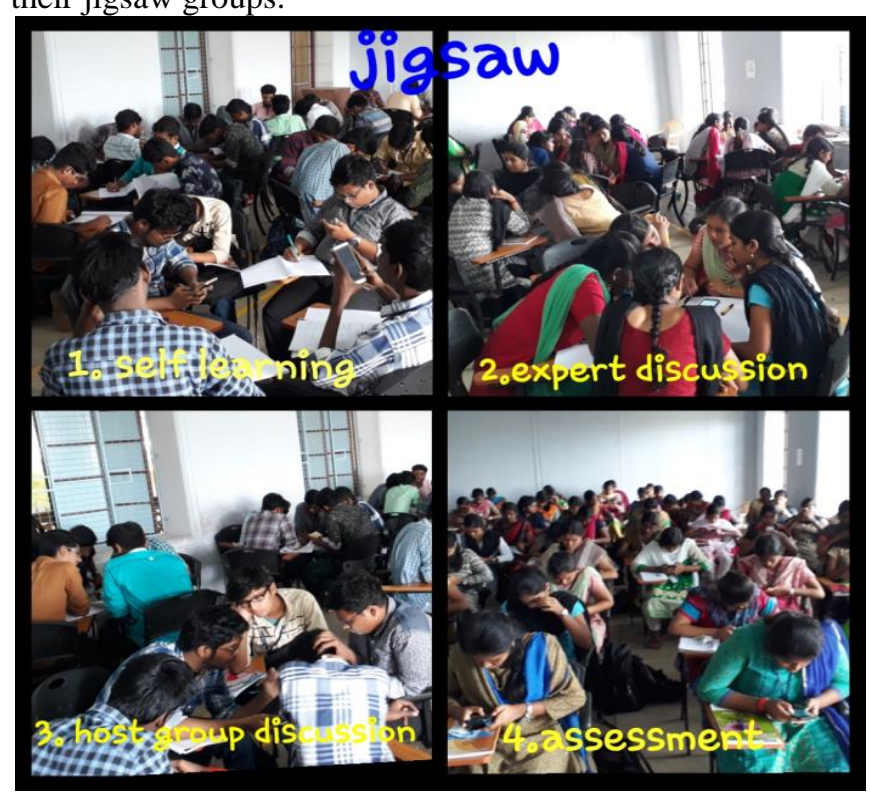

Figure 4 students involvement in Jigsaw

Students are asked to present her or his question to the group. At the end of the session, give an online quiz is conducted on the material.

\section{Discussions on Result}


Two groups of students are considered Group A with 75 students taught the concept using conventional lecture method and Group B with 75 students taught the concept using Jigsaw strategy. In CAT II exam the student's performance were analysis based on selection of questions taught using Jigsaw strategy and their average performance mark score by the students

Table -IV comparison of two groups

\begin{tabular}{|l|l|l|}
\hline & Group 1 & Group 2 \\
\hline Selection of C1 & $63 \%$ & $79 \%$ \\
\hline $\begin{array}{l}\text { Average marks scored } \\
\text { in the last activity of } \\
\text { Jigsaw }\end{array}$ & NA & $69 \%$ \\
\hline $\begin{array}{l}\text { Average marks scored } \\
\text { in the question }\end{array}$ & $6.5^{*}$ & $8^{*}$ \\
\hline
\end{tabular}

*out off 10 mark

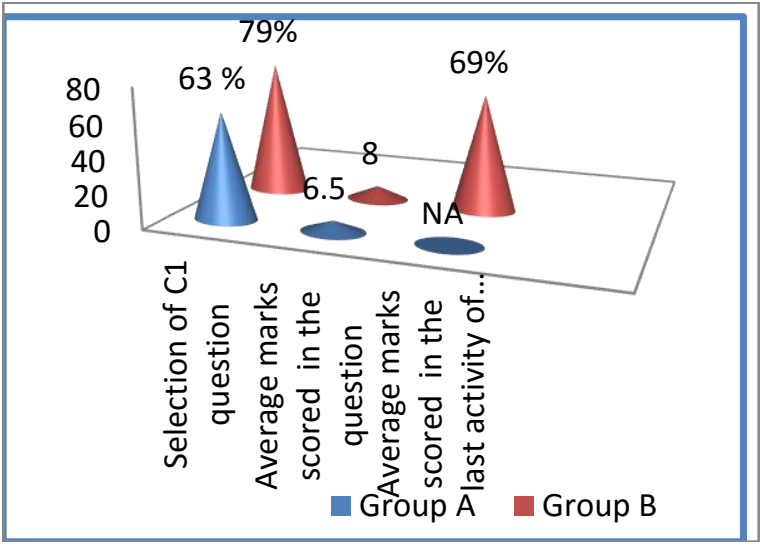

Figure 5 Performance Analysis of Group A and B

Question C1 is from the concept for which they do jigsaw activity. From the analysis of CAT-II results, it is found that students give more preference to the question related to Jigsaw activity in either- or choice question. $\mathrm{C} 1$ is mostly preferred by students than C2.Comparing the marks scored by two groups. Group A students got average score explained in figure 5 . Survey regarding the activity of Jigsaw technique is conducted based on Group B. The feedback questions are given in Table

Table V Feedback questions and responses

\begin{tabular}{|c|c|c|c|c|c|c|}
\hline \multirow{2}{*}{$\begin{array}{l}\text { Question } \\
\text { No }\end{array}$} & \multirow[t]{2}{*}{ Question } & \multicolumn{5}{|c|}{ No. of Student Response } \\
\hline & & 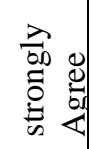 & 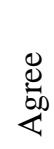 & 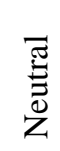 & 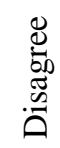 & 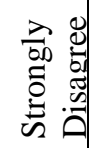 \\
\hline Q1 & $\begin{array}{l}\text { I enjoyed the } \\
\text { activity }\end{array}$ & 55 & 15 & 2 & 3 & 0 \\
\hline $\mathrm{Q} 2$ & $\begin{array}{l}\text { Learning } \\
\text { outcomes are } \\
\text { attained } \\
\text { through the } \\
\text { activity }\end{array}$ & 43 & 25 & 5 & 2 & 0 \\
\hline
\end{tabular}

\begin{tabular}{|l|l|l|l|l|l|l|}
\hline Q3 & $\begin{array}{l}\text { Activity is } \\
\text { planned and } \\
\text { implemented } \\
\text { well }\end{array}$ & 52 & 22 & 1 & 0 & 0 \\
\hline Q4 & $\begin{array}{l}\text { My } \\
\text { participation } \\
\text { in the activity } \\
\text { is good }\end{array}$ & 47 & 13 & 9 & 6 & 0 \\
\hline Q5 & $\begin{array}{l}\text { I anticipate } \\
\text { the activity in } \\
\text { future classes } \\
\text { also }\end{array}$ & 61 & 14 & 0 & 0 & 0 \\
\hline
\end{tabular}
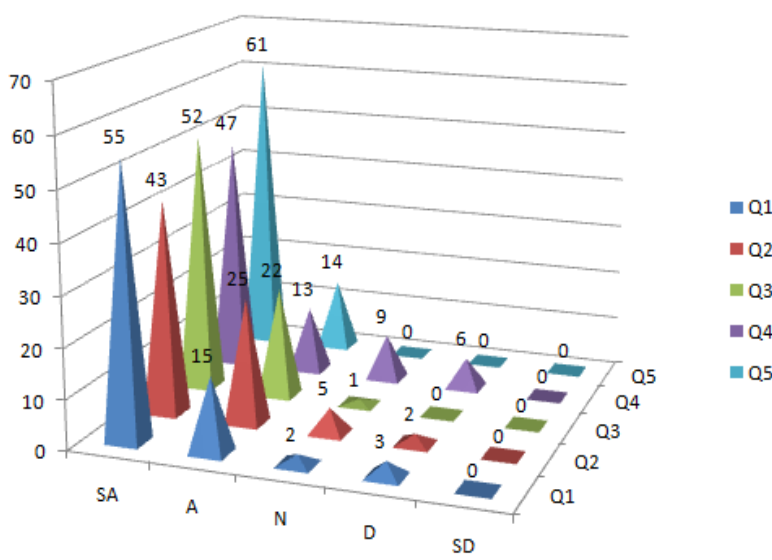

- Q2

Q Q3

Q4

a.5

Figure -6 Feedback analyses

\section{Conclusion}

Based on feedback it is inferred that, the Jigsaw activity was helpful to students in terms of self learning, team work and cooperative learning. It provides an opportunity to understand the concepts and applications. The student learning method based on Jigsaw technique is very active in the class room, enjoyed with the strategies used and felt satisfied with the assessment methods. Active learning makes the students more comfort in learning effectively and improve the understandability of COs. The CAT II results and the Students feedback obtained for the selected course justified the requirement of using active learning tools. This case study proves that, active learning is best methodology to increases the students understanding and performance in the examination.

\section{References}

1. DeNeve, K. M., \& Heppner, M. J. (1997). Role play simulations: The assessment of an active learning technique and comparisons with traditional lectures. Innovative Higher Education 21, 231-246.

2. Elliot, L. B. (1993). Using debates to teach the psychology of women. Teaching of Psychology 20, 3538.

3. Somers, J. A., \& Holt, M. E. (1993). What's in a game? A Study of games as an instructional method in an adult education class. Innovative Higher Education 17, 243-257.

4. Desai, S.V., Joshi, G.H., Tennalli, G.B., Patil, R.R. 2016). Molecular Skit- Role-play as a pedagogical tool for teaching molecular biology as an under-graduate 
engineering course Journal of Engineering Educatrion Transformations, 29(3)138-142.

5. Bell, S. (2010). Project-Based Learning for the 21st Century: Skills for the Future. Journal. The Clearing House: A Journal of Educational Strategies, Issues and Ideas. 83 (2) 39-43.

6. D. Kavitha, D.Anitha(2018).Flipped Classroom Using ICT Tools to Improve Outcome for the Course 'Soft Computing' - A Case Study: Journal of Engineering Education Transformations, Volume 32 , No. 2, October 2018, ISSN 2349-2473, eISSN 2394-1707

7. S. Julius Fusic, D.Kavitha, N.Anandh:A case study of implementing active learning techniques in electrical machine course: Journal of Engineering Education Transformations ,Volume 32 , No. 1, July 2018, ISSN 2349-2473, eISSN 2394-1707

8. Cynthia $\mathrm{J}$ et.al., "Work in Progress: Flipping the circuits classroom The impact of pre-class reading and in-class active learning on student and instructor",IEEE Global engineering education conference (EDUCON),(2017).

9. Florence Myrick, Wendy Caplan, Jayne Smitten, and Kerry Rusk(2011), "Preceptor/mentor education: A world of possibilities through e-learning", Nurse Education Today, 31(3), 263-267.

\section{Annexure-1}

The following are the questions used for assessment of both batches

Question asked in the exam

\begin{tabular}{|c|c|c|}
\hline \multicolumn{2}{|c|}{ Part A } & $\begin{array}{l}5 \times 4=20 \\
\text { Marks }\end{array}$ \\
\hline A1. & \multicolumn{2}{|c|}{ Define Microprocessor. Give any two examples. } \\
\hline A2. & \multicolumn{2}{|l|}{ Define CISC and RISC. } \\
\hline A3. & \multicolumn{2}{|l|}{ State any four applications of Microcontroller. } \\
\hline A4. & \multicolumn{2}{|c|}{$\begin{array}{l}\text { Write the internal memory capacity of } 8051 \\
\text { Microcontroller. }\end{array}$} \\
\hline A5. & \multicolumn{2}{|c|}{ State the alternate functions of Port 3.} \\
\hline \multicolumn{2}{|c|}{ Part B } & \\
\hline B1. & $\begin{array}{l}\text { With neat diagram, explain the internal } \\
\text { structure of any two ports in } 8051 \\
\text { Microcontroller. }\end{array}$ & $\begin{array}{l}10 \\
\text { Marks }\end{array}$ \\
\hline B2. & $\begin{array}{l}\text { Explain the interrupts of } 8051 \\
\text { Microcontroller along with their vector } \\
\text { address and special function registers } \\
\text { associated with interrupts. }\end{array}$ & $\begin{array}{l}7 \\
\text { Marks }\end{array}$ \\
\hline B3. & $\begin{array}{l}\text { If timer } 1 \text { is operated in mode } 2 \text { and count } \\
\text { value in } \mathrm{TH} 1=(\mathrm{FA}) \mathrm{H} \text {. Calculate the baud } \\
\text { rate if Oscillator frequency }=11.0592 \\
\mathrm{MHz} \text {. Assume SMOD bit }=0 \text {. }\end{array}$ & \begin{tabular}{|l|}
3 \\
Marks
\end{tabular} \\
\hline \multicolumn{2}{|c|}{ Part C } & 10 Marks \\
\hline
\end{tabular}

C1. Develop algorithm and embedded $\mathrm{C}$ program to generate $250 \mathrm{~Hz}$ square waveform using timer 0 of 8051 Microcontroller at port pin P1.4. Draw the interfacing diagram.

(OR)

C2. Interface $4 \mathrm{X} 4$ key pad as shown in the following figure 1 and LCD with 8051 and write an embedded $\mathrm{C}$ program to execute the following task: If key1 is pressed, your name is displayed in the first row of LCD. If key2 is pressed, your register number is displayed in the second row of LCD.

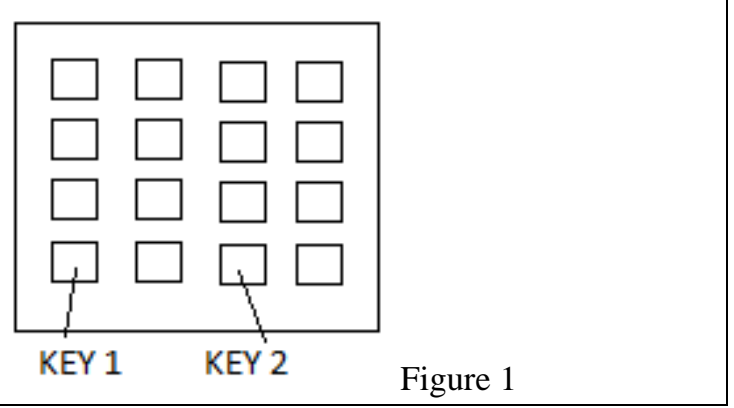

